\title{
Quality and Safety in Blood Supply in 2010
}

\author{
Rainer Seitz Margarethe Heiden \\ Division of Hematology/Transfusion Medicine, Paul-Ehrlich-Institut, Langen, Germany
}

\author{
Keywords \\ Blood supply · HIV · NAT testing · Adverse reaction · \\ Regulatory authority
}

\section{Summary}

The past two decades saw tremendous achievements in blood safety, which are due to the commitment of blood establishments and industry, progress in technology such as the improvement of serological and NAT screening tests, and stringent regulatory control. Milestones in the legislation were the inclusion of plasma derivatives in the pharmaceutical legislation of the European Community $(E C)$ in the year 1989 and special laws for the blood sector in EC and in member states, such as the Transfusionsgesetz (Transfusion Law) in Germany. The legal frame has to be supplemented by scientific and technical guidance, which is provided on the European level by the European Directorate for the Quality of Medicines and Health Care and by the European Medicines Agency. In the member states, guidelines taking into account the national peculiarities can be elaborated, such as the German hemotherapy guidelines issued by the German Medical Association (Bundesärztekammer) in agreement with the Paul-Ehrlich-Institut. The regulatory control of screening tests, and the introduction of NAT testing lead to a remarkably high degree of safety concerning the most relevant viruses HIV, HBV and HCV. Issues needing further attention are bacterial contamination and transfusion-associated acute lung injury (TRALI). Measures aiming at minimizing risks have to be balanced against their impact on supply. In order to ensure the assured supply with safe blood products, sustained efforts and research are needed as well as a continuous dialogue among blood services, industry, physicians, patients and regulatory authorities.

\author{
Schlüsselwörter \\ Blutversorgung · HIV · NAT-Testung · Nebenwirkungen · \\ Behörde
}

\section{Zusammenfassung}

Die letzten beiden Jahrzehnte sahen enorme Errungenschaften in der Blutsicherheit, die dem Engagement der Blutspendedienste und der Industrie, Fortschritten in der Technologie wie der Weiterentwicklung von serologischen und NAT-Screeningtests und stringenter behördlicher Kontrolle zu verdanken sind. Meilensteine in der Gesetzgebung waren die Aufnahme der Plasmaderivate in die pharmazeutische Gesetzgebung der Europäischen Gemeinschaft (EG) im Jahr 1989 sowie Spezialgesetze für den Blutsektor in der EG und den Mitgliedstaaten wie das Transfusionsgesetz in Deutschland. Der gesetzliche Rahmen muss durch wissenschaftliche und technische Leitfäden ergänzt werden, die auf europäischer Ebene vom European Directorate for the Quality of Medicines and Health Care und der European Medicines Agency zur Verfügung gestellt werden. In den Mitgliedstaaten können Leitfäden erarbeitet werden, die die nationalen Gegebenheiten berücksichtigen, wie die Hämotherapierichtlinien, die von der Bundesärztekammer im Einvernehmen mit dem Paul-Ehrlich-Institut herausgegeben werden. Die behördliche Kontrolle der Screeningtests und die Einführung der NAT-Testung führten zu einem bemerkenswert hohen Grad der Sicherheit hinsichtlich der relevantesten Viren HIV, HBV und HCV. Probleme, die weiterer Aufmerksamkeit bedürfen, sind bakterielle Kontamination und transfusionsassoziierte akute Lungeninsuffizienz (TRALI). Maßnahmen, die auf die Minimierung von Risiken abzielen, müssen gegen ihre Auswirkungen auf die Versorgung abgewogen werden. Um die sichere Versorgung mit sicheren Blutprodukten zu gewährleisten, sind anhaltende Anstrengungen und Forschung erforderlich ebenso wie ein kontinuierlicher Dialog zwischen Blutspendediensten, Industrie, Ärzten, Patienten und Behörden.

\begin{tabular}{ll}
\hline KARGER & $\oplus$ 2010 S. Karger GmbH, Freiburg \\
Fax +497614520714 & Accessible online at: \\
Information@Karger.de & www.karger.com/tmh \\
www.karger.com &
\end{tabular}




\section{Introduction}

Blood products, i.e. both blood components for transfusion and plasma derivatives, are essential therapeutics in state-ofthe-art medicine. Red blood cell transfusions save lives in emergencies or permit crucial interventions. Blood coagulation factor concentrates brought about a dramatic improvement in life expectancy and quality of life of hemophilia patients. For a long time, blood products were considered as pure replacement of physiological material, which would not be expected to be harmful. In the early 1980s, however, in a great number of cases infectious viruses, particularly the emerging human immunodeficiency virus (HIV), were transmitted by blood products, both blood components and plasma derivatives. This was one of the worst incidents of modern therapy, which highlighted drastically that there are indeed severe hazards. In addition to the possibility of pathogen transmission, also other potential adverse reactions are inherent to the use of blood products, such as unwanted immune reactions (e.g. hypersensitivity, allergy or induction of interfering antibodies). Thus, a clear need for precautionary measures and regulatory control was perceived.

In Europe - as well as in other industrialized areas - huge efforts towards blood product safety have been made by all involved parties, particularly blood establishments and industry as well as regulatory authorities. This induced tremendous progress in development and application of advanced technology, which is for example illustrated by the evolution and introduction of test systems for viral markers. In parallel, a comprehensive system of regulatory control [1] was set up, the basis of which is stringent legislation on both the European Community (EC) and member state (national) levels.

\section{Legislation and Authorities}

A consequence on the field of plasma-derived medicinal products, drawn in the EC legislation from the numerous blood-borne transmissions of HIV and other viruses, was directive $89 / 381 / \mathrm{EC}$ in the year 1989 , which was later integrated in the Community code relating to medicinal products for human use [2]. As a consequence, plasma derivatives - just as pharmaceuticals - need a marketing authorization (MA). Several MA procedures are available: A purely national procedure applies only for products to be distributed in one single EC member state. But in essence, the regulation of plasma derivatives is nowadays governed and managed on the European level. If a product is intended for more than one member state, MA is granted through the mutual recognition procedure or the decentralized procedure [2]. For certain innovative products, a centralized procedure [3] is foreseen. More detailed information about the procedures can be found in a recent review [1]. The MA holders have to install a pharmacovigilance system to ensure that infections and other adverse reactions are evaluated and reported to the competent authorities. A further element of safety is the official batch release by a network of official medicines control laboratories (OMCL) of the member states, which is coordinated by the European Directorate for the Quality of Medicines and Health Care (EDQM, Strasbourg). Another division of the EDQM, the European Pharmacopoeia (EP) issues the mandatory monographs, which codify technical standards for plasma for fractionation [4] and plasma derivatives. Important recommendations covering relevant aspects from the quality and safety of the starting material to the clinical evaluation of the products are provided in guidance documents [5] issued by the European Medicines Agency (EMA, London). An example is the Note for Guidance on Plasma-Derived Medicinal Products [6], which is currently under revision. Thus, several institutions contribute to the standardization and high quality of plasma derivatives [7]. Since the collected plasma is the starting material of several products, the Plasma Master File [8] was introduced in 2003 as a further regulatory instrument, which supports a consistent content and structure of the plasma documentation and its regular update. The production of plasma derivatives has to follow good manufacturing practice (GMP), which is reinforced by the competent authorities through official inspections.

Blood transfusion is part of the medical practice which has to be regulated by the member states. Blood components for transfusion are still not considered proprietary medicinal products in most member states. However, Article 152 in the chapter 'Public Health' of the Treaty establishing the European Union [9] states that the EC may adopt 'measures setting high standards of quality and safety of organs and substances of human origin, blood and blood derivatives; these measures shall not prevent any Member State from maintaining or introducing more stringent protective measures'. With Article 152 as legal basis, a dedicated 'blood law', directive 2002/98/EC [10], was adopted in 2003, which marks a broad regulatory framework for the official control of blood components for transfusion. This directive was supplemented by the more technical 'daughter' directives 2004/33/EC [11], 2005/61/ EC [12] and 2005/62/EC [13]. While the purpose of the pharmaceutical legislation according to provisions of Article 95 of the Treaty [9] - applicable to the plasma derivatives - is the free movement of therapeutic goods throughout the EC, the overall goal of the directive 2002/98/EC is that European citizens can trust to find a common good standard in all member states. An exchange of blood components for transfusion across borders is not intended by this legislation. This is in accordance with medical practice since blood components are normally not imported or exported, with the exception of emergencies or rare blood groups. Scientific and technical recommendations are provided by the very influential guide [14] of the Council of Europe, which has recently been transferred into the responsibility of the EDQM. 
In Germany, blood products had become completely subject to the Drug Law (Arzneimittelgesetz; AMG) [15] in the late 1970s. Peculiarities of blood donation, testing, hemovigilance and use of blood products were addressed by a special law, the Transfusion Act (Transfusionsgesetz; TFG) [16] in the year 1998. It is a special feature of this law, in contrast to the AMG, that not only quality, safety and efficacy of the products are addressed but also a quality assurance system for the use of blood products is required. This quality assurance system has to be adequately furnished and implemented by the top management of hospitals and other health care facilities and is based on the personal responsibility of physicians particularly experienced in hemotherapy. The TFG, providing the legal frame, is supplemented by technical guidelines [17] which are issued and continuously updated by the German Medical Association (Bundesärztekammer) in mutual agreement with the Paul-Ehrlich-Institut. The TFG has also attributed an important role to the German Blood Advisory Board (Arbeitskreis Blut) which is located at the Robert Koch-Institut. The Arbeitskreis Blut is a forum for consultation of experts according to the TFG and publishes recommendations ('Votum') concerning ongoing problems, e.g. look-back procedures [18]. Since 1994, the Paul-Ehrlich-Institut is responsible for MA of blood components. The Paul-Ehrlich-Institut is also empowered to impose corrective or precautionary measures as mandatory conditions. This mechanism proved to be important for the timely and nationwide implementation of new technologies, such as leukocyte depletion or NAT testing [19]. In order to verify the content of the MA dossiers and compliance of the manufacture of blood components with GMP, official inspections of blood establishments are performed.

All regulatory measures aiming at increased blood product safety have to be balanced against their potential negative impact on supply. For illustration, in the discussion about precautionary measures to prevent any potential propagation of variant Creutzfeldt-Jakob disease (vCJD), it had been proposed to ban all those from blood donation who had already themselves received blood. However, regarding the situation in Germany, a model calculation [20] showed that this would bring about only a marginal gain in safety, but on the expense of a considerable loss of motivated blood donors. Therefore, after careful consideration [21], this measure was finally rejected. The German TFG also takes account of the necessity to ensure a safe supply of the population with blood products. To this end, the TFG requires the report of data on collection, manufacture, import and export as well as usage of blood and blood products. The Paul-Ehrlich-Institut has built up a data base which can be accessed online by those obliged to report, evaluates the data and publishes regularly reports on the supply situation [22].

\section{Challenges and Solutions}

As said before, the most pressing issue which triggered the enhancement of regulatory control was the virus safety of blood products. The mass transmission of HIV was particularly in focus, but also the transmission of hepatitis $\mathrm{B}(\mathrm{HBV})$ and hepatitis $\mathrm{C}$ viruses ( $\mathrm{HCV}$ ) by blood products, the serious consequences of which had been neglected for a long time, was now understood as a burning issue. HIV was at that time an emerging pathogen [23] which was not yet characterized, and thus diagnostic tools were not yet available. Moreover, the serious clinical manifestation, the acquired immunodeficiency syndrome (AIDS), of HIV infection, was inevitable in those times - without the treatment options of today - but occurred only after a long, clinically silent lag phase. The infected individual develops an antibody response which, however, does not clear HIV from the circulation. This means that infected individuals would feel well and fit for blood donation for a long time while there is persistent HIV viremia. Thus, HIV is readily transmitted by contact with blood and other body fluids, e.g. by injection equipment shared by i.v. drug users and by sexual route, particularly under men having sex with men. The latter consideration fuelled strategies to minimize the risk of transmission by blood products by means of enhanced donor selection criteria, deferring persons with risk behavior from blood donation [11].

Much effort was invested in developing sensitive screening tests for markers of HIV and other virus infections, which lead to remarkable sensitivity and specificity of the test systems. Due to the high significance of these in vitro diagnostic devices for blood safety, there are particular regulatory requirements [24]. Nevertheless, the performance of serological test systems is not uniform [25], and it is important that blood establishments choose their screening tests carefully. After introduction of mandatory NAT in screening for HIV and HCV in Germany, a number of transmissions could be prevented, and only singular breakthrough cases were observed [26].

Mandatory NAT testing for HCV was introduced in Europe also for plasma pools used for production of plasma derivatives by the revision of the monograph [4] in 2001; many manufacturers perform NAT testing for further viruses on a voluntary basis. This has largely reduced the contamination frequency and viral loads of manufacturing plasma pools and thereby improved the safety margin [27]. In addition, since the 1980s effective steps in the manufacture of plasma derivatives became mandatory, which inactivate and/or remove relevant viruses such as HIV, HBV and HCV. The efficacy of such methods has to be demonstrated in experiments with down-scaled production steps, as explained by a special EMA guideline [28]. More recently, pathogen inactivation methods have been developed also for blood components.

Thus, three protective walls have been built up against virus transmission: donor criteria aiming at collecting blood from low-risk donor populations, testing of the donations with 
sensitive methods including NAT, and elimination of pathogens from the product. Blood safety regarding the most relevant viruses is now very high in Europe, with only a few recent transmissions by blood components. Recently, the German hemovigilance data, according to reports to the PaulEhrlich-Institut, have been summarized [29]. In the years 1997-2008, a total of only 47 transmissions of viral infections were recorded. This is a remarkably low number, in relation to about 4.5 million whole blood and 1.8 million apheresis donations per year in Germany. As a matter of fact, following the introduction of mandatory NAT testing, only one single transfusion-transmitted HCV case [30] since 1999 and one single HIV case [31] since 2001 has been reported. Thus, the measures taken in order to increase viral safety were clearly effective [29]. Likewise, in the past 10 years, there was no documented transmission of HIV, HCV or HBV by plasma derivatives licensed in the EC. The efforts and financial input behind these safety achievements are very substantial, but appear to have been a good investment since the confidence of the public in the safety of blood has largely been restored.

While the virus safety reached a remarkably high level, other risks continue to be associated with blood transfusion [32]. One of the issues with blood donation is the disinfection of the puncture site, which is of greatest relevance for avoidance of bacterial contamination of the blood components. Appropriate hygiene and standard operation procedures are imperative. A further element of safety is sterility testing of a certain share of the produced blood components. In Germany, as a result of these efforts, comparably low contamination rates could be shown [33]. One concept currently followed is complete sterility release testing of platelet concentrates and releasing them as 'sterile-to-date' [34]. Another approach is the use of pathogen inactivation methods as it was introduced in France due to an outbreak of Chikungunya virus on the island La Réunion [35]. Both concepts have an inherent caveat: Even if bacteria are absent at the time of testing or after applying inactivating methods, they may grow up afterwards to relevant numbers. Thus, the issue of bacterial contamination of blood components will need our further attention.

Another serious adverse reaction is transfusion-associated acute lung injury (TRALI). At least part of the cases is caused by donor antibodies against leukocytes of the recipient; thus a risk of TRALI is particularly associated with plasma-containing blood components. The causative antibodies can be directed to antigens in the human leukocyte antigen (HLA) or human neutrophil antigen (HNA) system and are elicited by contact of the donor with such antigens during pregnancy or upon blood transfusion. There is a well documented correlation of TRALI cases with the use of plasma from female donors with a history of pregnancies [36]. Thus, a strategy to prevent TRALI is to avoid the use of plasma from female donors. Another option would be testing for relevant antibodies. A recent achievement was the characterization of the clinically particularly relevant HNA-3a antigen [37].
A worrying and still not completely resolved problem is the propagation of vCJD. There is ample evidence showing that vCJD has been transmitted by the oral route, i.e. ingestion of contaminated materials; measures to clear the food chain of animals have apparently been effective, and both $\mathrm{BSE}$ and vCJD case numbers are declining. However, a large body of experimental and clinical data showing involvement of lymphatic tissue, and four cases of probable transmission of vCJD by transfused red cell concentrates prompted precautionary measures [21]. Since there is still no vCJD screening test for routine use, such measures mainly consist in donor selection criteria, e.g. stay in the UK, or a history of prion disease in the family. It has been reassuring that the purification methods used for manufacture of plasma products proved to remove to some extent also prion proteins. This was demonstrated by spiking experiments using various prion preparations and following their depletion in validation experiments. However, the recent post mortem observation of prion protein in the spleen of a hemophilia patient in UK [38] raised the possibility of transmission of the vCJD agent also by plasma derivatives. It has to be noted that the therapeutic preparation used by this patient was a factor VIII preparation of relatively low purity, and its manufacture method had only weak, if any, capacity to remove prions. Moreover, plasma sourced in the UK is no more used for manufacture of plasma derivatives since more than a decade. However, the use of products with validated capacity of the manufacture methods according to the guideline [39] continues to be important.

Blood safety is no longer a purely national issue. Blood products, particularly plasma derivatives, are exchanged across borders where conditions and health standards are quite different. Travellers may encounter situations abroad which necessitate blood transfusions. However, the status of blood systems and the adequacy of supply of the population with blood products of good quality and safety are apparently very different throughout the world. Pathogens continue to originate, evolve or re-emerge, and may rapidly be spread by the ever-growing international travel. Recent examples of emerging (new and newly relevant) pathogens include West Nile Virus and the Chagas' disease agent while older recognized pathogens like malaria continue to be a problem. Under these circumstances, it is a great challenge to adopt and keep updated safety measures, which take account of domestic factors (e.g. epidemiology of the donor population, transfusion practices as well as priorities in face of limits to available resources), while being harmonized as much as possible with other regions.

International collaboration is of crucial importance in promoting safety and availability of blood and blood products globally. The World Health Organization (WHO) is a key player. Also scientific and professional societies such as the International Society for Blood Transfusion (ISBT) will be important in this process. 


\section{Outlook}

The safety of blood products has reached a high degree. There is a continuing dynamic development of technologies, such as test systems or pathogen inactivation methods, the benefits, risks and costs of which will have to be scrutinized. The same is true for the upcoming innovative therapies based on hematopoietic stem cells.

Blood supply is a sensitive system, and blood donations are precious resource. Information of the public about the value and importance of blood as essential medicine needs to be intensified, as well as advertising for blood donation, both by blood services and official bodies. We will face fundamental demographic changes [40], resulting in a shrinking donor population. At the same time the proportion of elderly people will increase, who are likely to require more medical treatments and transfusions. This means that all measures aiming at improvements of blood safety need to be carefully balanced against supply. The upper age limit for blood donation may be adjusted, taking into account the longer life expectancy and improved health of future ageing generations. However, we should have in mind not only the collection and manufacture of safe blood products but also their responsible and critical use. Recently, the European initiative for optimal use of blood has been continued with a second symposium in Wildbad Kreuth in April 2009. Still, the consumption of blood components is quite variable throughout Europe, and the elaboration and implementation of improved strategies to optimize the use of blood have been advocated.

All these challenges will necessitate a permanent dialogue among blood services, industry, physicians, patients, regulatory authorities and other stakeholders. And, last but not least, we will need continuing research, e.g. into the biology and epidemiology of pathogens, technologies of testing and manufacture of blood products, and their best use in the interest of our patients.

\section{Disclosure}

The authors declared no conflict of interest.

\section{References}

1 Seitz R, Heiden M, Nübling CM, Unger G, Löwer J: The harmonization of the regulation of blood products: a European perspective. Vox Sang 2008;94: 267-276.

2 Directive 2001/83/EC of the European Parliament and of the Council of 6 November 2001 on the Community code relating to medicinal products for human use. Official Journal of the European Communities, L 311/67, 28.11.2001.

3 Regulation (EC) No 726/2004 of the European Parliament and of the Council of 31 March 2004 laying down Community procedures for the authorisation and supervision of medicinal products for human and veterinary use and establishing a European Medicines Agency. Official Journal of the European Union, L 136/1, 30.4.2004.

4 Human Plasma for Fractionation (0853). European Pharmacopoeia, 6th ed, volume 2. Strasbourg, European Directorate for the Quality of Medicines of the Council of Europe (EDQM), 2007.

5 www.ema.europa.eu

6 Guideline on Plasma-Derived Medicinal Products (CPMP/BWP/269/95 rev. 4) Strasbourg, EMEA, (released for consultation).

7 Seitz R: Standardisation of plasma products. Transfus Med Hemother 2003;30:124-128.

8 Seitz R, Haase M: Stammdokumentationen: weniger Papier, mehr Inhalt. Bundesgesundheitsbl Gesundheitsforsch Gesundheitsschutz 2008;51:764-770.

9 Consolidated Versions of the Treaty on European Union and of the Treaty Establishing the European Community, Official Journal of the European Union, C $321 \mathrm{E} / 1,29.12 .2006$

10 Directive 2002/98/EC of the European Parliament and of the Council of 27 January 2003 setting standards of quality and safety for the collection, testing, processing, storage and distribution of human blood and blood components and amending Directive 2001/83/EC. Official Journal of the European Union, L 33/30, 8.2.2003.
11 Commission Directive 2004/33/EC of 22 March 2004 implementing Directive 2002/98/EC of the European Parliament and of the Council as regards certain technical requirements for blood and blood components. Official Journal of the European Union, L 91/25, 30.3.2004

12 Commission Directive 2005/61/EC of 30 September 2005 implementing Directive 2002/98/EC of the European Parliament and of the Council as regards traceability requirements and notification of serious adverse reactions and events. Official Journal of the European Union, L 256/32, 1.10.2005.

13 Commission Directive 2005/62/EC of 30 September 2005 implementing Directive 2002/98/EC of the European Parliament and of the Council as regards Community standards and specifications relating to a quality system for blood establishments. Official Journal of the European Union, L 256/41, 1.10 .2005

14 Guide to the preparation, use and quality assurance of blood components, Recommendation No. R (95) 15, 14th ed. Strasbourg, Council of Europe Publishing, 2008.

15 Arzneimittelgesetz in der Fassung der Bekanntmachung vom 12. Dezember 2005 (BGBl. I S. 3394), zuletzt geändert durch Artikel 1 der Verordnung zur Bestimmung von Dopingmitteln und Festlegung der nicht geringen Mengen vom 28. September 2009 (BGBl. I S. 3172), in Kraft getreten am 03. Oktober 2009.

16 Transfusionsgesetz in der Fassung der Bekanntmachung vom 28. August 2007 (BGBl. I, Nr. 45, S. 2169, 5. September 2007).

17 Richtlinien zur Gewinnung von Blut und Blutbestandteilen und zur Anwendung von Blutprodukten (Hämotherapie) gemäß $\S \S 12$ u. 18 TFG vom 19. September 2005, Bundesanzeiger vom 5. November 2005, Sonderheft Nr. 209a.
18 Arbeitskreis Blut, Votum 34: Verfahren zur Rückverfolgung (Look Back) (gemäß $§ 19$ Transfusionsgesetz). Bundesgesundheitsbl Gesundheitsforsch Gesundheitsschutz 2006;49:940-957.

19 Stufenplan: Bekanntmachung über die Ergebnisse des Stufenplanverfahrens zur Verminderung des Risikos von Hepatitis B-, Hepatitis C- und HIVInfektionen bei Empfängern von Erythrozytenkonzentraten (Bundesanzeiger Nr. 63 vom 04.04.1997, S. 4477) vom 25. Februar 1998. Bundesanzeiger vom 18. März 1998, Nr. 53, S.3835.

20 Dietz K, Raddatz G, Wallis J, Müller N, Zerr I, Lefèvre H, Seifried E, Löwer J: Blood transfusion and spread of variant Creutzfeldt-Jakob disease. Emerg Infect Dis 2007;13:89-96.

21 Seitz R, von Auer F, Blümel J, Burger R, Buschmann A, Dietz K, Heiden M, Hitzler WE, Klamm H, Kreil T, Kretzschmar H, Nübling M, Offergeld R, Pauli G, Schottstedt V, Volkers P, Zerr I: Impact of vCJD on blood supply. Biologicals 2007;35:79-97.

22 Henseler O, Heiden M, Haschberger B, Hesse J, Seitz R: Report on notifications pursuant to $§ 21$ German Transfusion Act for 2007. Transfus Med Hemother 2010;37:29-47.

23 Arbeitskreis Blut, Untergruppe 'Bewertung Blutassoziierter Krankheitserreger': Human immunodeficiency virus (HIV). Transfus Med Hemother 2004:31:102-114.

24 Directive 98/79/EC of the European Parliament and of the Council of 27 October 1998 on in vitro diagnostic medical devices. Official Journal of the European Communities, L 331/1, 7.12.1998.

25 Nick S, Scheiblauer H: Sensitivities of CE-marked HIV, HCV, and HBsAg assays. J Med Virol 2007; 79(suppl 1):S59-S64 
26 Nübling CM, Heiden M, Chudy M, Kress J, Seitz R, Keller-Stanislawski B, Funk MB: Experience of mandatory nucleic acid test (NAT) screening across all blood organizations in Germany: NAT yield versus breakthrough transmissions. Transfusion 2009;49:1850-1858.

27 Nübling CM, Unkelbach U, Chudy M, Seitz R: Effect of viral nucleic acid testing on contamination frequency of manufacturing plasma pools. Transfusion 2008;48:822-826.

28 Guideline on virus validation studies: the design, contribution and interpretation of studies validating the inactivation and removal of viruses (EMEA/CPMP/ BWP/268/95)

29 Funk MB, Günay S, Lohmann A, Henseler O, Keller-Stanislawski B: Bewertung der Maßnahmen zur Reduktion schwerwiegender Transfusionsreaktionen (Hämovigilanzdaten von 1997 bis 2008). Bundesgesundheitsblatt 2010;53:347-356.

30 Kretzschmar E, Chudy M, Nübling CM, Ross RS, Kruse F, Trobisch H: First case of hepatitis $\mathrm{C}$ virus transmission by a red blood cell concentrate after introduction of nucleic acid amplification technique screening in Germany: a comparative study with various assays. Vox Sang 2007;92:297-301.

31 Schmidt M, Korn K, Nübling CM, Chudy M, Kress J, Horst HA, Geusendam G, Hennig H, Sireis W, Rabenau H, Doerr HW, Berger A, Hourfar MK, Gubbe K, Karl A, Fickenscher H, Tischer K, Babiel R, Seifried E, Gürtler L: First transmission of human immunodeficiency virus Type 1 by a cellular blood product after mandatory nucleic acid screening in Germany. Transfusion 2009;49:1836-1844.

32 Keller-Stanislawski B, Lohmann A, Günay S, Heiden M, Funk MB: The German Haemovigilance System - reports of serious adverse transfusion reactions between 1997 and 2007. Transfus Med 2009;19:340-349.

33 Walter-Wenke G, Doerner R, Montag T, Greiss O, Hornei B, Knels R, Strobel J, Volkers P, Däubener W: Bacterial contamination of platelet concentrates prepared by different methods: results of standardized sterility testing in Germany. Vox Sang 2006;90:177-182.

34 Dumont LJ, Kleinman S, Murphy JR, Lippincott R, Schuyler R, Houghton J, Metzel P: Screening of single-donor apheresis platelets for bacterial contamination: the PASSPORT study results. Transfusion 2009; DOI: $10.1111 /$ j.15372995.2009.02460.x

-35 Rasonglès P, Angelini-Tibert MF, Simon P, Currie C, Isola H, Kientz D, Slaedts M, Jacquet M, Sundin D, Lin L, Corash L, Cazenave JP: Transfusion of plate let components prepared with photochemical pathogen inactivation treatment during a Chikungunya virus epidemic in Ile de La Réunion. Transfusion 2009;49:1083-1091.

36 Keller-Stanislawski B, Reil A, Günay S, Funk MB: Frequency and severity of transfusion-related acute lung injury - German haemovigilance data (20062007). Vox Sang 2010;98:70-77.

37 Greinacher A, Wesche J, Hammer E, Fürll B, Völker U, Reil A, Bux J: Characterization of the human neutrophil alloantigen-3a. Nat Med 2010;16:45-48.

38 Peden A, McCardle L, Head MW, Love S, Ward HJ, Cousens SN, Keeling DM, Millar CM, Hill FG, Ironside JW: Variant CJD infection in the spleen of a neurologically asymptomatic UK adult patient with haemophilia. Haemophilia 2010; DOI: $10.1111 / \mathrm{j} .1365-2516.2009 .02181 . x$

39 Guideline on the Investigation of Manufacturing Processes for Plasma-Derived Medicinal Products with Regard to vCJD risk, CPMP/BWP/5136/03.

40 Greinacher A, Fendrich K, Alpen U, Hoffmann W: Impact of demographic changes on the blood supply: Mecklenburg-West Pomerania as a model region for Europe. Transfusion 2007;47:395-401. 